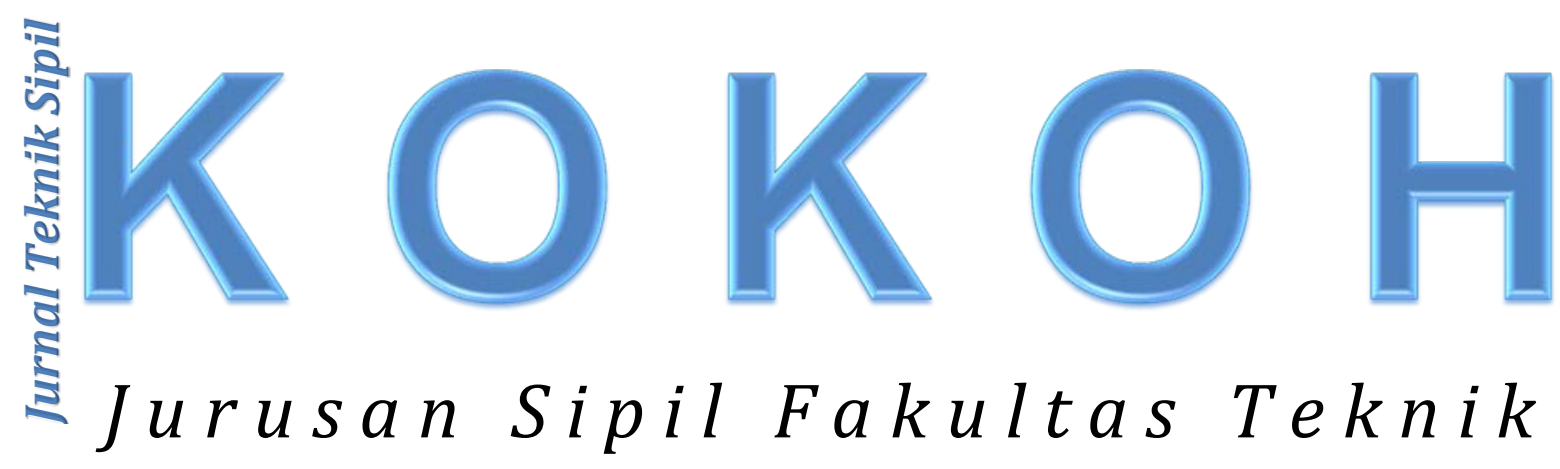

Volume 11 No. 3

Desember 2010

ISSN : $1411-3864$

Pengaruh Penambahan Pasir Terhadap Stabilisasi Tanah Ekpasnsif Menggunakan Aspal Emulsi

(Fauzy Lebang)

Analsis Karakteristik Campuran Beton Aspal (AC-WC) dan (AC-BC) Dengan Menggunakan Abu Gunung Berapi Makian Sebagai Filler

(Tamrin Mallawangeng)

Sistem Perencanaan Pembuangan Limbah Septik Tank Secara Komunal (Andi Rumpang Yusuf)

Komparasi Hasil Perhitungan Tebal Lapis Tambahan Perkerasan Lentur Jalan Dengan Beberapa Metode Studi Kasus : Ruas Jalan Lapuko - Tobimeta Sulawesi Tenggara (Syahrul Sariman)

Studi Pengaruh Redistribusi Momen Terhadap

Daktilitas Struktur (Arman Setiawan)

Pengaruh Variasi Persentase Kandungan Styrofoam Pada Beton Terhadap Lendutan Maksimum Balok Beton Bertulang (Eka Yuniarto)

Yayasan Andi Sose

Universitas " 45 " Makassar 


\title{
STUDI PENGARUH REDISTRIBUSI MOMEN TERHADAP DAKTALITAS STRUKTUR
}

\author{
Oleh : Arman Setiawan ${ }^{1)}$
}

\begin{abstract}
The combined effect of gravity loads and seismic forces often results in frame moment patterns that do not allow efficient design of beam and column members. Even in the seismic dominated regular frame, where gravity load moments are approximately 30\% of seismic moments, the resulting combination of gravity and seismic moments results in the maximum negative beam moment being about 2.5 times the maximum positive moment. In line with load increasing, plastic hinges may occur at other locations along the span and may trigger structure collapse but this is only possible when redistribution moment occurs. The structure analysis used is SAP 2000 Version 10.01 and analysis of non-linear static pushover using Drain 2DX for evaluation and plastic hinge mechanism. Redistribution moment analysis produces an average moment reduction of $30 \%$. This result is later analysed with DRAIN 2DX to calculate non-linear static pushover analysis both before and after redistribution moment. After the analysis, it is found that the structure ductility is 2.42 before redistribution moment and 3.58 after redistribution moment. The result proves that this method can be used as an alternative design for reinforced concrete frame.
\end{abstract}

\section{Keyword : Moment redistribution, symmetrical reinforced concrete frame, nonlinear static pushover.}

\section{PENDAHULUAN}

Kebanyakan struktur beton bertulang dianalisis dengan mempergunakan teori elastis. Kekuatan struktur didesain dengan memperhitungkan daerah inelastis dan respons struktur pada pembebanan yang berlebih. Pada analisis elastis, digunakan beban yang terfaktor untuk menentukan momen-momen yang terjadi pada struktur tersebut. Setelah itu, bagianbagian struktur tersebut didesain dengan memperhatikan bahwa tulangan baja akan memasuki daerah leleh dan distribusi tegangan pada beton akan menjadi non-linear sebelum akhirnya runtuh. Hal ini adalah

\footnotetext{
1) Dosen Teknik Sipil Universitas 45 Makassar
} 
pendekatan yang tidak konsisten. Tetapi evaluasi keseluruhan struktur terhadap kekuatan batas yang sebenarnya memerlukan analisis yang tidak mudah dan terperinci. Oleh karena itu dipergunakan prosedur yang aman di mana struktur tersebut kemudian dianalisis dan didesain untuk dapat menahan beban yang lebih besar daripada beban yang diperhitungkan dengan menggunakan kekuatan batas.

Umumnya pada struktur balok atau rangka, kelebihan kapasitas akan dihasilkan pada bagian lain tersebut, karena pada bagian tersebut telah diperkuat berdasarkan momen yang dihasilkan distribusi beban yang berbeda untuk memperoleh momen maksimum pada bagian yang lain tersebut. Sejalan dengan peningkatan beban, sendi plastis yang terjadi dapat terbentuk pada bagian yang lain sepanjang bentang dan dapat menyebabkan keruntuhan struktur tersebut, tetapi hal ini terjadi hanya setelah redistribusi momen terjadi.

Efek kombinasi beban gravitasi dan gaya gempa sering menghasilkan pola momen portal yang tidak memungkinkan desain balok dan kolom yang efisien. Pada portal yang didominasi beban gempa, momen akibat beban gravitasi kira-kira 30 \% dari momen akibat gempa. Hasil kombinasi momen akhir menghasilkan momen negatif maksimum sekitar 2,5 kali momen positif maksimum.

Akibat filosofi desain daktilitas yaitu gaya desain harus lebih kecil dari tingkat respons elastis yang sebenarnya, dan yang akan terjadi pada gaya gempa desain adalah kekuatan balok aktual bukan gaya pada tingkat desain. Oleh karena momen balok dan kolom total pada suatu joint harus dalam keseimbangan, kelebihan kapasitas momen balok harus dicocokkan dengan kapasitas momen kolom tambahan sehingga sendi plastis pada kolom dapat dihindari. Gaya geser balok dan kolom aktual akan meningkat dengan cara yang sama. Riwayat momen dapat diatur oleh redistribusi momen untuk menghasilkan solusi struktur yang rasional dan efisien tanpa mengorbankan keamanan struktur atau menggangu keseimbangan di bawah beban aplikasi. 
Berdasarkan uraian latar belakang di atas maka penulis ingin mengetahui pengaruh dari Redistribusi Momen terhadap daktilitas struktur dalam portal beton bertulang.

\section{TINJAUAN PUSTAKA}

\subsection{Dasar Pemikiran}

Bentuk matriks kekakuan dan metode analisis gaya yang diprogram untuk komputasi digital memberikan pendekatan yang sistematis terhadap studi struktur portal berlantai banyak. Beberapa program tersedia misalnya SAP2000, ETABS, DRAIN-2D hanya memerlukan spesifikasi material, kekakuan, geometri struktur dan pembebanan. Pada desain gempa, keuntungan dari beberapa analisis tersebut lebih diutamakan pada kecepatan pemprosesan data dibandingkan tingkat akurasi yang diinginkan. Analisis untuk beban atau kombinasi tertentu atau beban terfaktor dapat dengan segera diperoleh untuk struktur elastis dan efek kombinasi beban yang diinginkan dapat ditentukan dengan metode superposisi.

Pendekatan perilaku kekuatan struktur beton bertulang yang lebih akurat dan realistis dapat diperoleh dengan beberapa metode analisis nonlinear. Beberapa diantaranya terlalu kompleks dan membutuhkan waktu yang banyak. Dengan teknik yang ada sekarang ini, upaya komputasi yang terlibat dalam analisis nonlinear total pada bangunan bertingkat tinggi seringkali tidak diajurkan. Teknik analisis nonlinear tidak memiliki keuntungan khusus dalam perencanaan terhadap kombinasi gaya gempa dengan beban gravitasi.

Analisis elastis secara tradisional telah banyak digunakan untuk menentukan kekuatan rencana balok dan kolom pada sebuah portal dengan memperhatikan gaya-gaya dalam yang bekerja pada portal tersebut. Hal ini disebabkan analisis elastis memenuhi kriteria keseimbangan dan kompatibilitas deformasi elastis dengan pembatasan pada asumsi yang dibuat. Pada banyak kasus, hasil dari analisis elastis 
dapat langsung digunakan untuk memperoleh solusi praktis dan solusi ekonomis. Desain struktur yang lebih efisien diperoleh ketika gaya-gaya dalam disesuaikan / diatur dan diredistribusi dengan memperhatikan perilaku nonlinear, khususnya ketika gaya-gaya dalam mendekati kekuatan penuh struktur tersebut. Hal ini dilakukan secara teliti dengan memperhatikan kriteria keseimbangan. Dengan prinsip-prinsip umum telah dikenal dalam desain struktur beton bertulang, respons nonlinear juga telah banyak diketahui.

Redistribusi gaya-gaya yang diperkirakan oleh analisis elastis dengan pembatasan tertentu untuk memastikan kriteria serviceability juga dipenuhi dan potensial daktilitas daerah-daerah yang dipengaruhi tidak habis terpakai. Daerah sendi plastis potensial pada struktur beton gempa didetailkan dengan penanganan khusus untuk memenuhi kebutuhan daktilitas besar yang mungkin. Oleh karena itu, keuntungan perilaku non linear dapat dipergunakan sepenuhnya secara umum. Desain komponenkomponen portal diperoleh dari hasil analisis elastis yang dimodifikasi sehingga memungkinkan redistribusi inelastis terhadap gaya-gaya dalam. Kebanyakan struktur beton bertulang didesain untuk momen, gaya geser dan gaya batang dengan mempergunakan teori elastis. Kekuatan struktur didesain dengan memperhatikan daerah yang inelastis dan respons struktur pada pembebanan yang berlebih. Pada analisis elastis, digunakan beban yang terfaktor untuk menentukan momen-momen yang terjadi pada struktur tersebut. Setelah itu, bagian-bagian struktur tersebut didesain dengan memperhatikan bahwa tulangan baja akan memasuki daerah leleh dan distribusi tegangan pada beton akan menjadi non-linear sebelum akhirnya runtuh. Hal ini adalah pendekatan yang tidak konsisten.

Tetapi evaluasi keseluruhan struktur terhadap kekuatan ultimate dan kekuatan batas yang sebenarnya memerkukan analisis yang tidak mudah dan terperinci. Oleh karena itu dipergunakan prosedur yang aman dimana struktur tersebut kemudian didesain dan dianalisis untuk dapat 
menanggung beban yang lebih besar daripada beban yang diperhitungkan dengan analisis batas.

Umumnya, pada struktur balok atau rangka, kelebihan kapasitas akan dihasilkan pada bagian lain tersebut, karena pada bagian tersebut telah diperkuat berdasarkan momen yang dihasilkan distribusi beban yang berbeda untuk memperoleh momen maksimum pada bagian yang lain tersebut.

Sejalan dengan peningkatan beban, sendi plastis yang terjadi dapat terbentuk pada bagian yang lain sepanjang bentang dan dapat menyebabkan keruntuhan struktur tersebut, tetapi hal ini terjadi hanya setelah redistribusi momen terjadi.

\subsection{Sendi Plastis dan Mekanisme Keruntuhan}

Teori plastis hanya dapat berlaku pada material yang dapat berperilaku plastis. Hubungan ideal antara momen $\mathrm{M}$ terhadap rotasi $\theta$ ditunjukkan oleh gambar 1, dimana terdapat bagian elastis yang sempurna dan bagian plastis yang ideal.
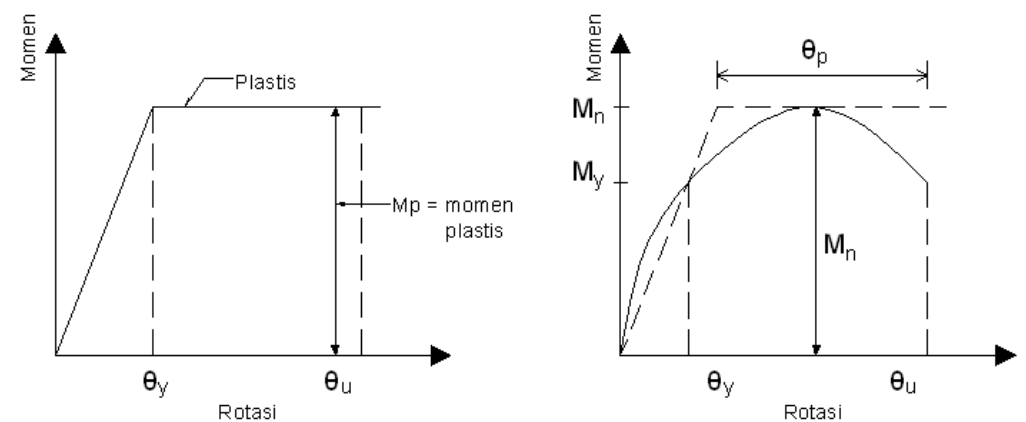

Gambar 1. Kurva Momen - Rotasi

Beban batas pada beberapa sistem dicapai ketika sudut rotasi pada beban tertentu mencapai nilai $\theta_{u}$ yaitu pada saat regangan beton mencapai regangan ultimate-nya. Pada analisis batas, momen maksimum $M_{n}$ yang dicapai pada saat regangan ultimate beton, adalah sesuai dengan momen plastis $M_{p}$ pada analisis plastis. 
Untuk balok yang ditumpu sederhana, pencapaian $M_{p}$ atau $M_{n}$ pada lokasi tertentu menunjukkan batas dari sistem tersebut. Setelah itu, bila diberikan peningkatan beban, maka balok tersebut akan berdeformasi lebih lanjut tanpa mempengaruhi resistansi balok tersebut. Akan terjadilah deformasi yang tak terkontrol dan struktur tersebut akan runtuh. Sistem yang dihasilkan disebut mekanisme. Struktur statis tertentu memerlukan pembentukan hanya satu sendi plastis untuk menjadi suatu mekanisme.

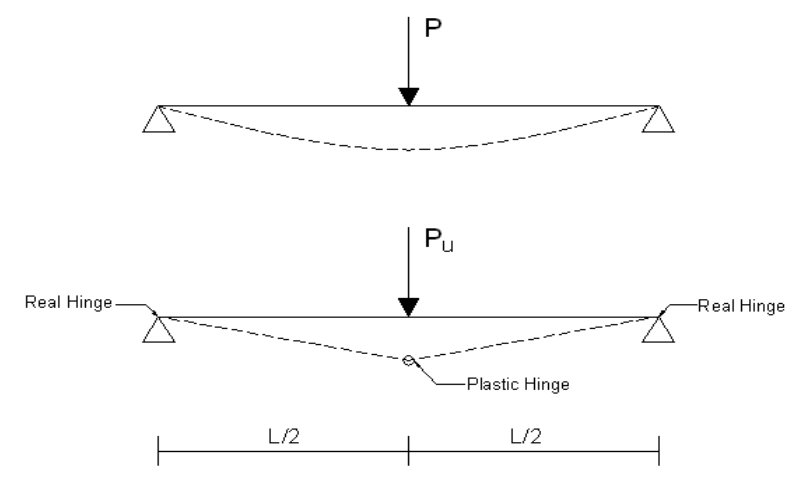

Gambar 2. Mekanisme Keruntuhan pada Balok Sederhana

Sedangkan struktur statis tak tentu, struktur masih berada dalam kestabilan walaupun sendi telah terbentuk pada beberapa irisan. Pada struktur statis tak tentu, pembentukan sendi plastis memungkinkan terjadinya redistribusi momen pada balok atau rangka. Hal ini terlihat pada struktur menerus, material pada bagian dimana $M_{p}$ pertama kali dicapai harus mengalami peningkatan regangan sebelum struktur tersebut mencapai kondisi batasnya. Penambahan regangan ini dengan memperhatikan bagian yang tertekuk disebut kapasitas rotasi.

Pada gambar 3a ditunjukkan sebuah sistem struktur statis tak tentu dengan ujung terjepit yang diberi beban merata sebesar w. Diagram momen yang dihasilkannya ditunjukkan pada gambar 3b. Dengan peningkatan beban, momen maksimum pada ujung yang terjepit mencapai Mp sementara pada daerah yang lain masih dalam batas elastis apabila kekuatan struktur seragam sepanjang bentang. 


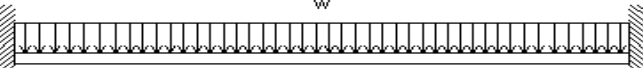

(a)

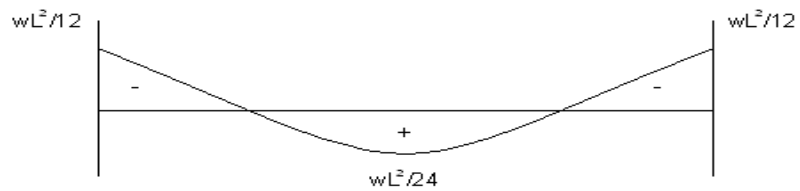

(b)

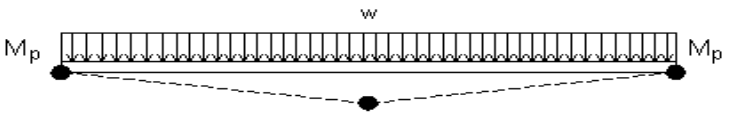

(c)

Gambar 3. Kondisi Batas Untuk Balok dengan Ujung Terjepit

Pada titik yang mencapai Mp di ujung-ujung balok berlaku,

$$
\frac{w_{y} L^{2}}{12}=M_{p} \quad \text { dan } \quad w_{y}=\frac{M_{y} L^{2}}{12}
$$

dimana $w_{y}$ adalah beban merata yang dipikul di ujung dengan kemiringan $\theta_{y}$ yang terjadi ketika momen $M_{p}$ baru saja tercapai. Ketika memikul beban tersebut, balok tersebut masih stabil seperti balok sederhana. Pada gambar 3c diatas kapasitas momen dapat meningkat $33 \%$ setelah momen plastis tercapai di ujung yang terjepit. Peningkatan kapasitas momen ini diperlukan untuk penambahan deformasi pada ujung terjepit sampai terjadinya momen plastis ditengah bentang. Dengan kata lain, setelah kapasitas rotasi terpenuhi, momen kapasitas positif dan negatif untuk beban tertentu akan menjadi seimbang, tentu saja dengan asumsi kekuatan pada kedua irisan di kedua daerah itu adalah sama.

Perilaku batas seperti tersebut diatas telah diperbaiki dalam struktur baja dan kegunaannya dalam desain plastis telah banyak digunakan. Baja yang merupakan material yang sangat daktail, menyebabkan balok dapat memikul kapasitas rotasi tingkat tinggi. Sementara itu, beban yang merupakan material yang relatif getas, tidak dapat memikul deformasi plastis. 


\subsection{Persyaratan Rotasi}

Besarnya rotasi yang diperlukan pada sendi plastis untuk setiap diagram momen dapat diperoleh dengan memperhatikan pernsyaratan kompatibilitas. Batang harus berdeformasi pada efek kombinasi antara momen elastis dan sendi plastis, sehingga dengan demikian kondisi batas yang benar dipenuhi pada perletakan.

\subsection{Kapasitas Rotasi}

Dari regangan elastis yang diperlihatkan pada Gambar 4a, sudut kelengkungan atau rotasi satuan pada leleh awal dapat diperoleh.

$$
\varphi_{y}=\frac{\varepsilon_{y}}{d(1-k)}
$$

Tinggi sumbu netral $k$ dapat dihitung dengan rumus

$$
\begin{aligned}
& k=\sqrt{\left(\rho_{n}\right)^{2}+2 \rho_{n}}-\rho_{n} \\
& \text { dimana } n=\frac{E_{s}}{E_{c}} \text {, dan } \rho=\text { rasio tulangan }=\frac{A_{s}}{b d}
\end{aligned}
$$

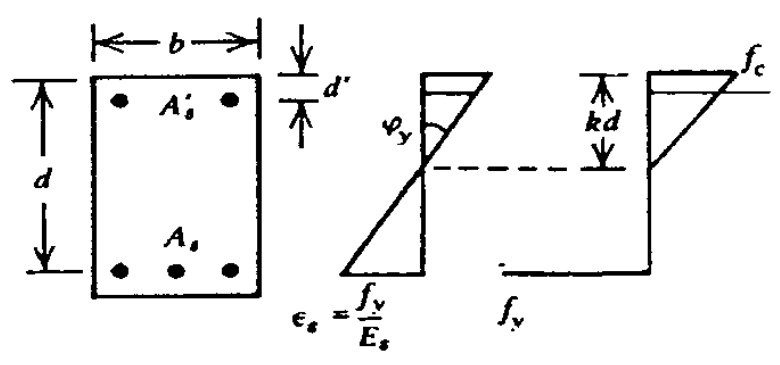

(a) regangan-tegangan pada awal proses kelelehan

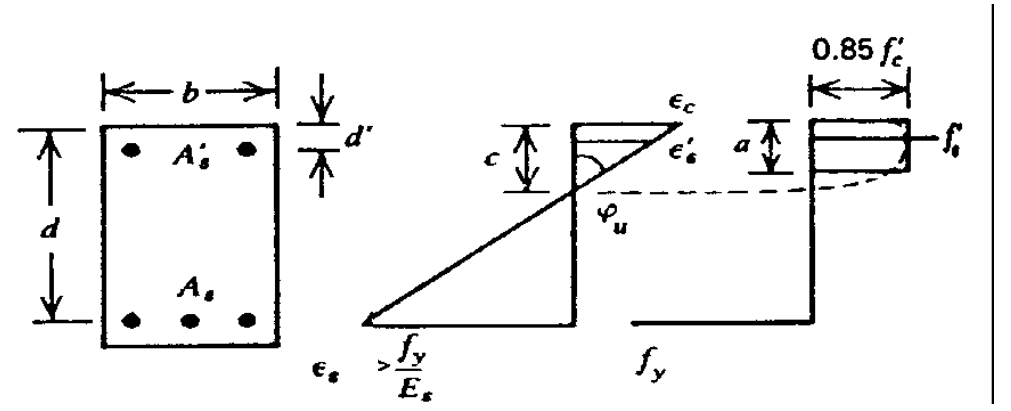

(b) regangan-tegangan pada awal keruntuhan

Gambar 4. Regangan-Tegangan Beton Bertulang Pada Saat Leleh dan Runtuh 
Rotasi satuan batas dapat ditemukan dari rumus :

$$
\varphi_{u}=\frac{\varepsilon_{c}}{c}
$$

Pada analisis kekuatan lentur dipakai $\varepsilon_{c u}=0.003$, tetapi untuk analisis batas, diperlukan nilai yang lebih teliti. Regangan batas lentur pada sebuah sendi plastis dapat ditentukan dari rumus empiris berikut

$$
\varepsilon_{c}=0.003+0.02 \frac{b}{z}+\left(\frac{\rho_{s} f_{y}}{20}\right)^{2}
$$

Dari persamaan-persamaan (1) sampai (4), rotasi satuan inelastis untuk hubungan yang diidealisaikan seperti yang diperlihatkan pada Gambar 1b dapat ditentukan.

$$
\varphi_{p}=\varphi_{u}-\varphi_{y} \frac{M_{n}}{M_{y}}
$$

Rotasi plastis tidak terjadi hanya pada satu daerah irisan tetapi didistribusikan pada suatu panjang tertentu yang disebut persendian (hinging length). Studi-studi percobaan yang menjadi dasar dari persamaan (4) didasarkan pada regangan dan rotasi yang terukur pada panjang tertentu sesuai dengan tinggi efektif $d$ dari batang yang ditest.

Oleh karena itu, $\varepsilon c u$ adalah nilai rata-rata regangan batas pada panjang tertentu dan $\varphi_{p}$ adalah nilai rata-rata unit rotasi. Rotasi inelastis total $\theta_{p}$ dapat diperoleh dengan mengalikan unit rotasi rata-rata terhadap panjang sendi.

$$
\theta_{p}=\left(\varphi_{u}-\varphi_{y} \frac{M_{n}}{M_{y}}\right) \cdot l_{p}
$$

Dari bukti-bukti yang didapatkan selama ini, panjang sendi Ip pada kedua daerah perletakan dapat diperhitungakan dengan persamaan 7

$$
I_{p}=0.5 d+0.05 z
$$

Dimana $z$ adalah jarak antara titik momen maksimum ke titik terdekat yang momennya sama dengan nol dan d adalah tinggi efektif balok.

Pemamfaatan penuh dari kapasitas plastis pada rangka kaku dan balok menerus beton bertulang memerlukan suatu analisis yang meluas dari 
semua kemungkinan mekanisme. Selain itu diperlukan pula suatu penyelidikan mengenai kapasitas dan kebutuhan rotasi pada semua kemungkinan lokasi terbentuknya sendi plastis. Waktu yang dibutuhkan untuk perencanaan tidak sebanding dengan hasil yang diperoleh. Sebaliknya, suatu jumlah tertentu dari redistribusi momen elastis dengan aman dapat dilakukan tanpa melakukan suatu analisis yang lengkap, tetapi sudah cukup untuk mendapatkan sebagian besar dari manfaat analisis batas.

\subsection{Redistribusi Gaya-gaya Desain}

Adanya efek kombinasi beban gravitasi dan gaya gempa yang sering menghasilkan momen portal yang tidak memungkinkan desain balok dan kolom yang efisien. Hal ini diilustrasikan pada Gambar 5(c) dan Gambar 5(d), yang menunjukkan bidang momen tipikal yang dapat dihasilkan oleh kombinasi dari beban gravitasi dan gaya gempa untuk satu lantai atau 2 macam portal. Momen-momen pada Gambar 5 dan 6 ditulis tanpa satuan dan besarnya digambar tanpa skala.
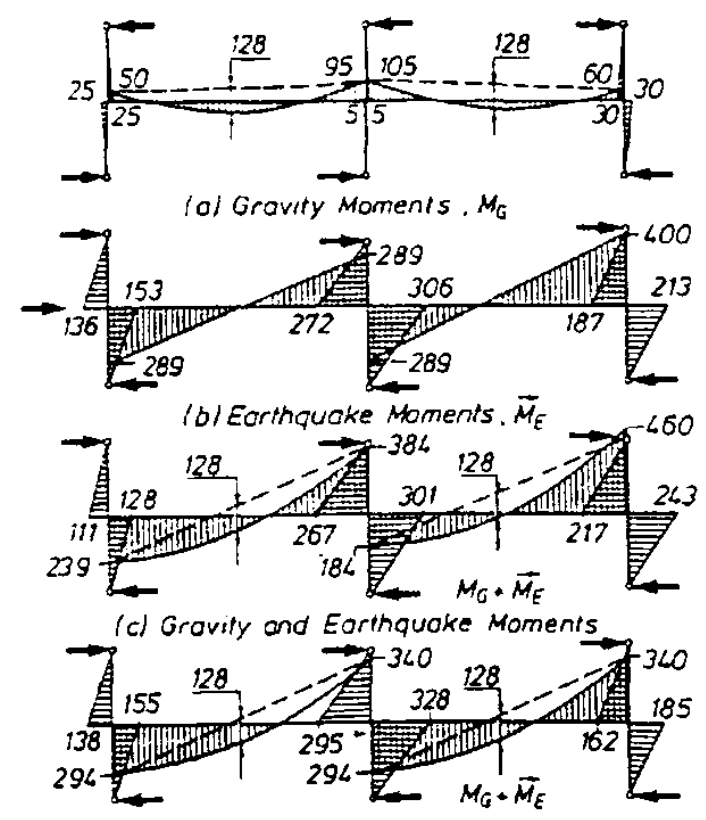

(d) Redistributed Grovity and Eorthquoke Moments

Gambar 5. Redistribusi momen desain pada rangka beraturan yang didominasi oleh beban gempa 


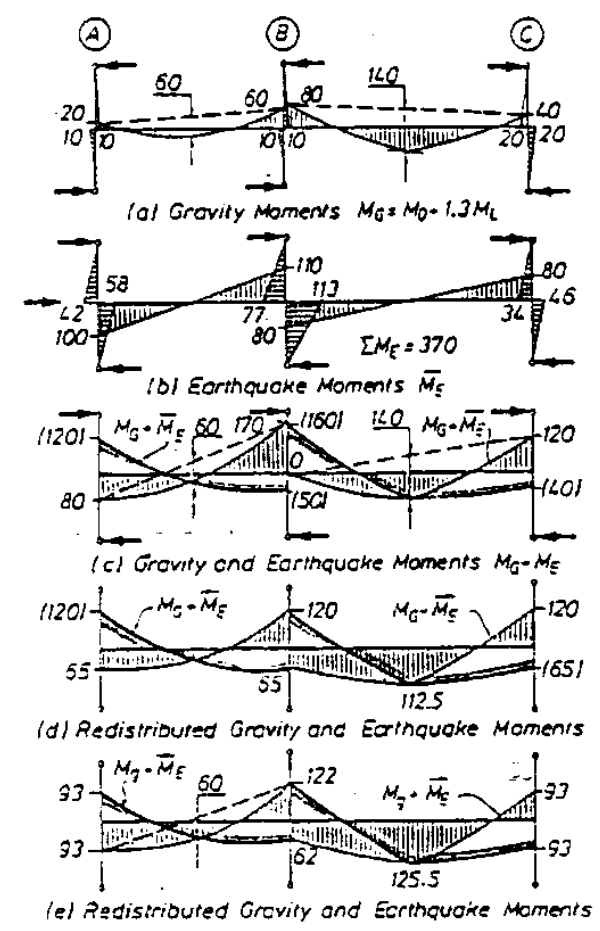

Gambar 6. Redistribusi momen desain pada rangka tidak simetris yang didominasi oleh beban

Gravitasi

Bidang momen pada gambar $5 \mathrm{c}$ dan $6 \mathrm{c}$ dapat dikurangi dengan redistribusi momen untuk menghasilkan desain struktur yang efisien dan lebih rasional tanpa mengabaikan tingkat keamanan dan keseimbangan gaya akibat beban yang bekerja.

\subsection{Tujuan Redistribusi Momen}

Kegunaan redistribusi momen balok portal daktail adalah untuk memperoleh desain struktur yang efektif dengan menerapkan hal-hal berikut :

1. Mengurangi momen maksimum absolut, biasanya pada daerah momen negatif dari balok dan mengimbanginya dengan meningkatkan momen tersebut pada daerah momen yang tidak kritis (noncritical), biasanya momen positif. Hal ini membuat kemungkinan distribusi yang lebih baik dari penggunaan kekuatan sepanjang balok. Penyesuaian akan dibuat sehingga momen negatif dan positif desain pada penampang kritis 
mendekati kesetaraan. Hal ini akan dihasilkan pada penguatan lentur sederhana dan pengaturan secara simetris pada daerah balok ini.

2. Menyamakan syarat momen kritis di daerah balok pada sisi yang berlawanan dari kolom interior yang dihasilkan dari arah yang berlawanan dari gempa yang diterapkan. Hal ini akan meniadakan kebutuhan untuk menghentikan dan mengangkur balok penguatan lentur pada joint balok-kolom interior.

3. Mempergunakan momen kapasitas positif minimum yang disyaratkan oleh peraturan apabila momen kapasitas positif minimum ini melebihi syarat yang diturunkan dari analisis elastis. Kebanyakan peraturan mensyaratkan momen kapasitas positif setidaknya sama dengan $50 \%$ dari momen kapasitas negatif pada permukaan kolom. Maksud dari ketentuan ini adalah untuk memastikan bahwa dengan kehadiran penguatan tegangan lentur, lengkungan daktilitas yang dibutuhkan telah siap untuk dikembangkan di bawah momen negatif yang besar,

4. Mereduksi kebutuhan momen pada kolom kritis, terutama sekali yang berhubungan dengan gaya tekan aksial kecil atau dengan gaya tarik aksial. Hal ini kadang-kadang akan penting untuk menghindarkan kebutuhan untuk menggunakan penguatan lentur berlebihan pada kolom tertentu.

\subsection{Petunjuk Redistribusi Momen}

Redistribusi momen dapat diterima jika tersedia rotasi daktilitas yang cukup pada titik kritis balok. Redistribusi ini akan mengurangi aksi yang bekerja pada batang dan kondisi leleh yang terjadi lebih kecil dari intensitas desain gaya lateral dan akan menahan kenaikan kebutuhan daktilitas rotasi. Namun, kebuturhan daktilitas global pada struktur akibat beban gempa tetap tidak berubah. Karena desain mensyaratkan sistem kolom kuat balok lemah, dimana daktilitas adalah syarat utama balok, gambaran khusus harus ditunjukkan pada penampang kritis balok untuk menjamin bahwa rotasi daktilitas yang tersedia dapat menahan beban 
gempa. Rotasi yang jauh lebih kecil diisyaratkan pada redistribusi beban elastis.

Proses redistribusi berdasar pada sendi platis balok. Redistribusi momen dan geser yang terjadi antara kolom juga berdasar pada rotasi sendi plastis balok.

Direkomendasikan bahwa setiap batang dari balok menerus pada portal daktail, momen maksimum dapat dikurangi hingga 30\% dari momen absolut yang ditentukan dari analisis elastis untuk kombinasi beban gempa dan gravitasi. Batasan ini untuk menjamin bahwa sendi plastis tidak terjadi dengan cepat akibat gempa sedang. Dan kebutuhan daktilitas rotasi balok tidak akan meningkat secara berlebihan. Hal - hal yang tidak akurat pada analisa elastis dapat mempengaruhi tingkat ketepatan reduksi. Pengaruh dari batas 30\% menyebabkan kondisi leleh mulai terjadi pada $70 \%$ tingkat desain. Karena pengurangan curvatur daktilitas pada beberapa penampang dapat menaikkan hingga $43 \%$. Hal ini dapat diterima jika persyaratan untuk daerah sendi plastis. Penambahan curva daktilitas pada beberapa penampang menghasilkan tegangan tarik yang lebih besar dari penambahan tegangan tekan beton.

\subsection{Persyaratan Keseimbangan pada Redistribusi Momen}

Persyaratan penting dari redistribusi momen adalah keseimbangan struktur akibat gaya gempa dan beban gravitasi harus dipertahankan. Gambar 7 menunjukkan subframe tipikal untuk portal multystory.

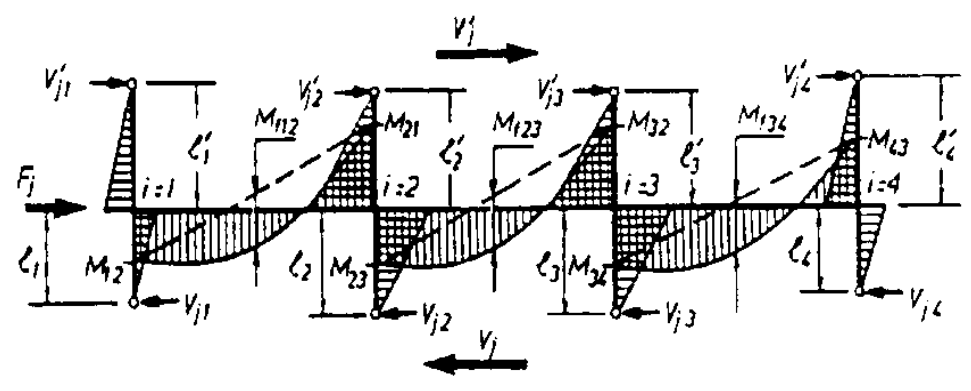

Gambar 7. Keseimbangan Subraframe 
Dengan pemotongan kolom pada atas dan bawah balok pada titik dimana momen $=0$ pada kolom, seperti gambar 5 dan 6. Pola momen yang ditunjukkan dari analisa elastis dari beban gempa gravitasi dan beban gempa yang bekerja secara simultan. Gaya geser total yang diterima oleh kolom bawah adalah $V_{j}$ dan kolom atas $V_{j}$ untuk arah gempa (E). Gaya geser kolom termasuk komponen gravitasi. Namun tidak ada struktur yang menerima gaya horizontal hanya dari beban gravitasi. Selanjutnya jumlah gaya geser kolom disetiap lantai yang merupakan beban gravitasi balok harus sama dengan 0 . Gaya geser $V_{j}$ d dan $V_{j}$ pada gambar 7 disebut gaya geser lantai yang seluruhnya diakibatkan oleh gaya lateral gempa seperti $F_{j}$.

Pada kriteria keseimbangan, asumsi sedehana bahwa jarak antara contraflexure dari dua kolom adalah sama untuk semua kolom pada portal. Jarak ini tidak akan berubah akibat redistribusi. Dari gambar $7 \mathrm{Cl}^{\prime}{ }^{+}$ $\left.I_{i}\right)=I_{c}$ adalah panjang yang konstan. Asumsi bahwa redistribusi momen pada balok di setiap lantai adalah jumlah gaya yang dihasilkan sama dengan gaya yang sebenarnya.

Kriteria keseimbangan dibuat dengan pemisahan gaya horizontal dan momen. Persyaratan keseimbangan gaya horizontal adalah

$$
v_{j}^{\prime}+F_{j}+V_{j}=\sum_{i} V_{j i}^{\prime}+F_{j}+\sum_{i} V_{j i}=0
$$

Gaya geser lantai

$$
v_{j}^{\prime}=\sum_{i} v_{j i}
$$

dan

$$
v_{j}=\sum_{i} v_{j i}
$$

Dimana $V_{j i}$ dan $V_{j i}$, masing-masing adalah gaya geser kolom pada kolom ke-i di atas dan di bawah balok tersebut, dan $F_{j}$ adalah gaya lateral yang bekerja pada tingkat ke-j yang dihitung dengan analisis elastis untuk keseluruhan struktur. Kedua persamaan di atas menyatakan bahwa 
beberapa atau seluruh gaya geser kolom dapat berubah pada sebuah lantai sewaktu redistribusi momen, tetapi gaya horizontal total pada lantai tersebut harus tetap konstan.

Persamaan 8 juga menunjukkan persamaan momen yang mudah dihitung. Pada gambar 7 dapat dilihat bahwa gaya geser yang bekerja pada kolom $M_{c i}=l_{i}^{\prime} \cdot V_{j i}^{\prime}+l_{i} \cdot V_{j i}$ pada joint balok menerus. Selama redistribusi momen kenaikan atau penurunan $\Delta M_{i}$ dapat dialihkan ke joint$i$.

Hal ini juga akan mengakibatkan perubahan gaya geser

$$
\Delta V_{i}=\frac{\Delta M_{i}}{l_{i}^{\prime}+l_{i}}=\frac{\Delta M_{i}}{I_{c}}
$$

Pada pengaruh kolom atas maupun di bawah lantai. Dari persamaan (8c), bahwa $\sum_{i}\left(v_{j i}+\Delta V_{i}\right)=\sum_{i} v_{j i}+\sum_{i} \Delta V_{i}=v_{j}=$ konstan, dan hal ini berati bahwa penjumlahan kenaikan gaya geser kolom $\sum_{i} \Delta V_{i}$ pada lantai atas dan bawah tingkat $j$ harus sama dengan nol. Akibatnya, dari persamaan (8d), jumlah kenaikan momen pada joint balok-kolom harus juga nol, karena $I_{C}=l_{i}+l_{i}^{\prime}$ adalah konstan (yaitu $\sum_{i} \Delta M_{i}=0$ ) dengan kata lain momen total yang bekerja pada suatu level pada portal adalah konstan. Persyaratan pada persamaan $8 a$ juga harus terpenuhi setelah redistribusi jika :

$$
\begin{aligned}
\sum_{i} M_{C i}+\sum_{i} \Delta M_{i} & =\sum_{i} I_{i}^{\prime}\left(V_{j i}^{\prime}+\Delta V_{i}\right. \\
& =\sum_{i} I_{i}^{\prime} V_{j i}^{\prime}+\sum_{i} l_{i} V_{j i}+\left(I_{i}^{\prime}+l_{i}\right) \sum_{i} V_{\Delta} \\
& =\sum_{i} M_{c i}=\text { kons tan }
\end{aligned}
$$

Selanjutnya gaya geser kolom $V_{j i}$ atau $V_{j i i}$ juga dapat berubah selama redistribusi, tetapi total momen input pada balok $\sum_{i} M_{c i}$, juga tetap tidak berubah. Selanjutnya momen yang bekerja pada ujung balok (gambar 7) juga harus memenuhi kondisi yang sama.

$$
\sum_{i} M_{c i}=\sum_{i}\left(M_{i, i-1}+M_{i+1}\right)=\sum_{i} M_{b i}=\text { momen tingkat }=\text { kons } \tan
$$




$$
\sum_{i} M_{c i}=M_{12}+\left(M_{21}+M_{23}\right)+\left(M_{32}+M_{34}\right)+M_{43}=\sum_{i} M_{b i}
$$

Dimana $\mathrm{M}_{\mathrm{bi}}$ adalah momen yang didistribusi ke kolom oleh balok yang berhubungan dengan kolom pada titik i.

Persamaan 9b menggambarkan bahwa besar momen ujung balok dapat berubah sepanjang jumlah dari momen ujung balok tetap tidak berubah. Praktisnya redistribusi momen dapat dilakukan jika memenuhi persamaan 9b dan persamaan 8. Hal ini karena keseimbangan disetiap titik harus dicapai. Penentuan momen desain kolom berdasarkan prosedur momen desain kapasitas dimana keseimbangan pada setiap sambungan harus terpenuhi.

\subsection{Desain Kapasitas}

Secara ekonomis tidaklah layak untuk merencanakan struktur-struktur gedung tinggi sedemikian kuat sehingga mampu menahan gempa kuat secara elastik. Sehubungan dengan itu di dalam Standar Perencanaan Ketahanan Gempa Untuk Struktur Bangunan Gedung SNI 1726 - 2002 ditetapkan suatu taraf gempa rencana untuk daktail penuh, dimana saat struktur dilanda gempa, tidak seluruh energi potensial yang tersimpan dikembalikan menjadi energi kinetik. Taraf gempa rencana yang ditetapkan tersebut bertujuan agar suatu struktur gedung tidak rusak saat dilanda gempa-gempa kecil dan sedang, tetapi saat dilanda gempa kuat struktur tersebut mampu melakukan perubahan bentuk secara daktail dengan memancarkan energi gempa dan membatasi gaya gempa yang masuk ke dalam struktur.

Untuk menghasilkan perilaku yang baik setelah struktur melampaui batas elastisnya, maka mekanisme terjadinya sendi plastis pada komponenkomponen struktur perlu dikendalikan. Perencanaan penempatan dan pengendalian sendi-sendi plastis ini merupakan konsep dasar dari Desain Kapasitas. 


\section{METODOLOGI PENELITIAN}

\subsection{Jenis dan Teknik Penelitian}

Jenis penelitian merupakan telaah literatur yang tidak semata-mata bersifat teoritis, tetapi telah diverifikasi melalui penelitian oleh Paulay \& Pristley di Amerika Serikat.

Kasus yang ditinjau adalah suatu portal simetrik beton bertulang tingkat sedang berlantai delapan sehubungan pembatasan dalam implementasi analisa struktur dengan redistribusi momen.

Teknis analisis struktur yang digunakan dalam penulisan ini adalah menggunakan aplikasi program SAP 2000 Versi 10.01 dan analisis statik non liniar pushover menggunakan Drain 2DX sebagai evaluasi kinerja dalam mekanisme sendi plastis.

\section{HASIL PENELITIAN DAN PEMBAHASAN}

\subsection{Data Struktur Gedung dan Model Struktur Bangunan}

Suatu portal beton bertulang terletak di atas tanah sedang pada zona gempa 2. Struktur akan dianalisis dan diterapkan evaluasi mekanisme sendi plastis pada struktur tersebut, dengan dimensi-dimensi utama sebagai berikut :

$\begin{array}{ll}\text { Panjang denah } & \mathrm{L}=36 \mathrm{~m} \\ \text { Lebar denah } & \mathrm{B}=25 \mathrm{~m} \\ \text { Jumlah lantai } & \mathrm{n}=8 \text { lantai } \\ \text { Tinggi total struktur } & \mathrm{h}=33 \mathrm{~m} \\ \text { Mutu beton } & \mathrm{f}^{\prime} \mathrm{c}=30 \mathrm{Mpa} \\ \text { Mutu tulangan } & \mathrm{fy}=350 \mathrm{Mpa}\end{array}$


Struktur yang didesain adalah struktur beton bertulang bangunan berlantai delapan portal terbuka (open frame) dengan peninjauan portal tiga dimensi berdasarkan Sistem Rangka Pemikul Momen Menengah (SRPMM). Berikut ini ditampilkan model struktur beserta dimensinya.

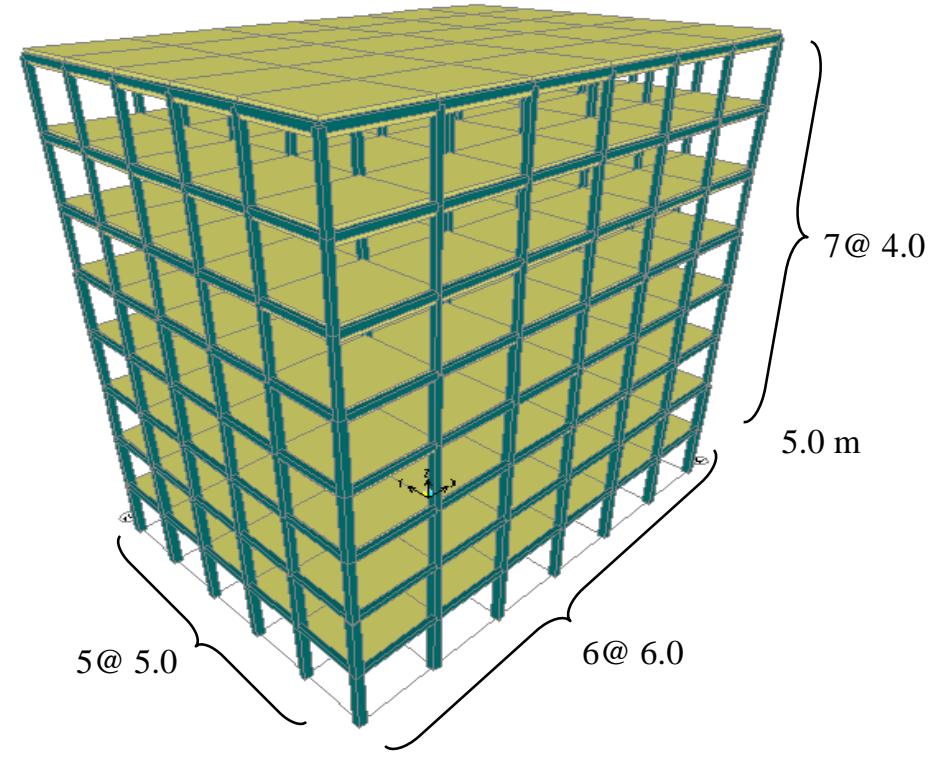

Gambar 8 Perspektif Struktur Portal Beton Bertulang 3D

\subsection{Perhitungan Struktur dengan Redistribusi Momen}
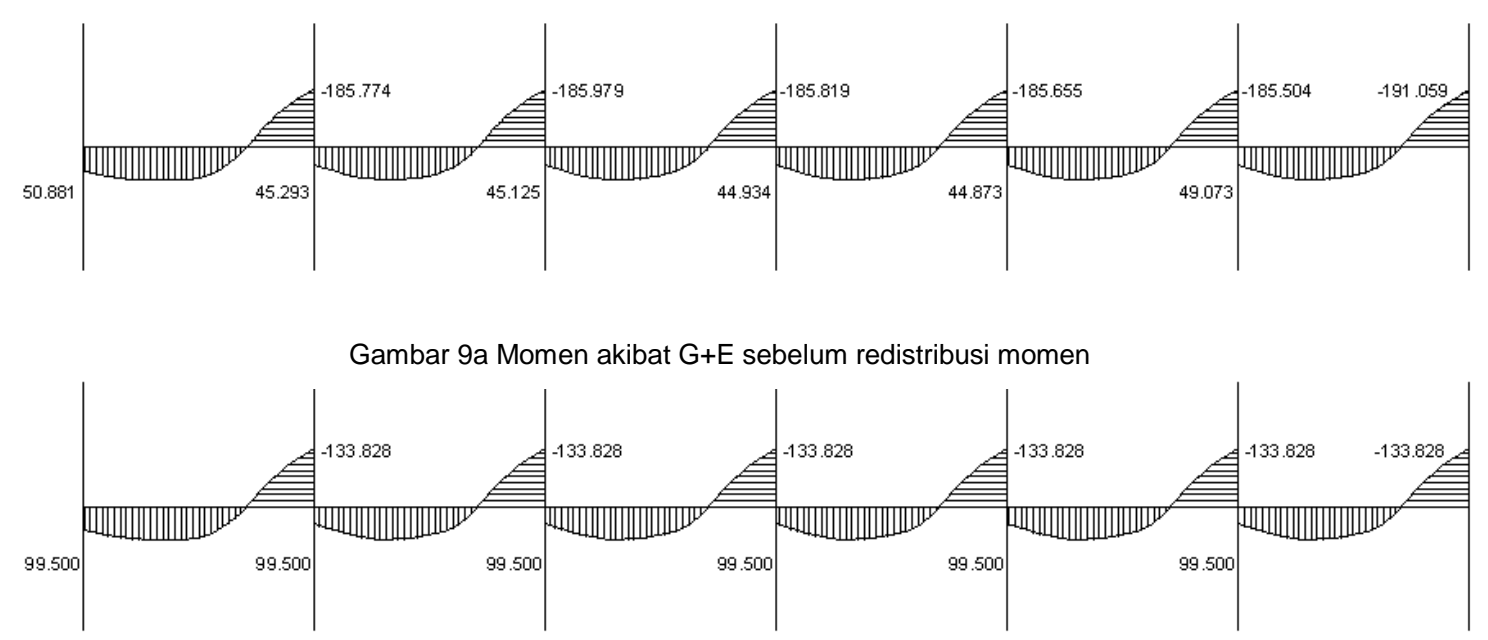
Outline proses redistribusi dapat dilihat pada gambar 9a dan 9b. Portal simetris gambar 9a memenuhi persyaratan :

$$
\begin{aligned}
\Sigma_{\mathrm{i}} \mathrm{M}_{\mathrm{bi}}= & 50.881+185.774+45.294+185.979+45.125+185.819+ \\
& 44.934+185.655+44.873+185.504+49.074+191.0593 \\
= & 1399.97 \mathrm{KNm}
\end{aligned}
$$

Jumlah ini tidak boleh berkurang setelah proses redistribusi.

Pada semua sendi plastis terjadi momen yang sama yaitu 1399.97/12 = $116.662 \cong 117.0 \mathrm{KNm}$. Pengurangan maksimum pada momen kritis $191.0593 \mathrm{KNm}$ adalah $0.7 \times 191.0593=133.7415 \mathrm{KNm}>117.0 \mathrm{KNm}$. Momen negatif tetap lebih besar dari momen positif pada pusat kolom. Akibatnya momen negatif balok $133.828 \mathrm{KNm}$ dan momen positif 99.50 $\mathrm{KNm}$ adalah dari pusat kolom. Seperti gambar 4.5b.

$$
\Sigma_{\mathrm{i}} \mathrm{M}_{\mathrm{bi}}=6 \times 133.828+6 \times 99.50=1399.9701 \mathrm{KNm} \text {. }
$$

\subsection{Implementasi Terhadap Daktalitas Struktur}

Besar gaya gempa yang menyebabkan terbentuknya sendi-sendi plastis pada ujung-ujung balok pada tiap lantai dan pada kolom-kolom bagian bawah diperlihatkan pada Tabel 1 lokasi-lokasi terbentuknya sendi-sendi plastis diperlihatkan pada gambar 10 dan gambar 11.

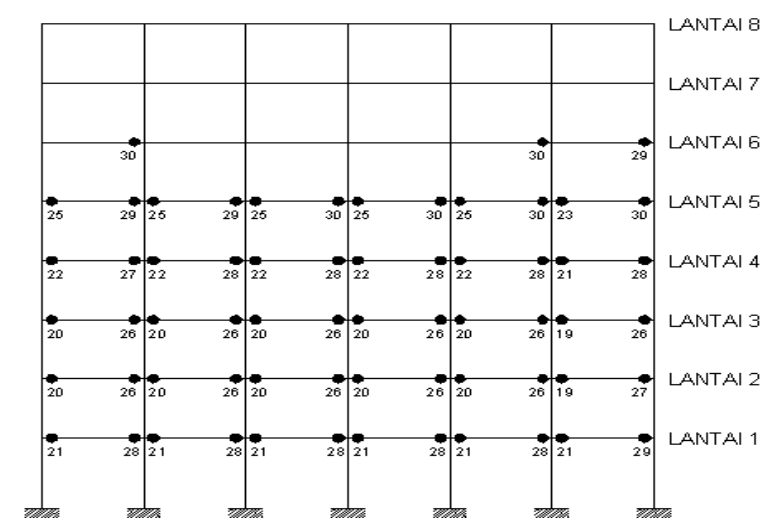

Gambar 10.a Lokasi Terbentuknya Sendi Plastis Sebelum Redistribusi Momen Portal XZ_1 


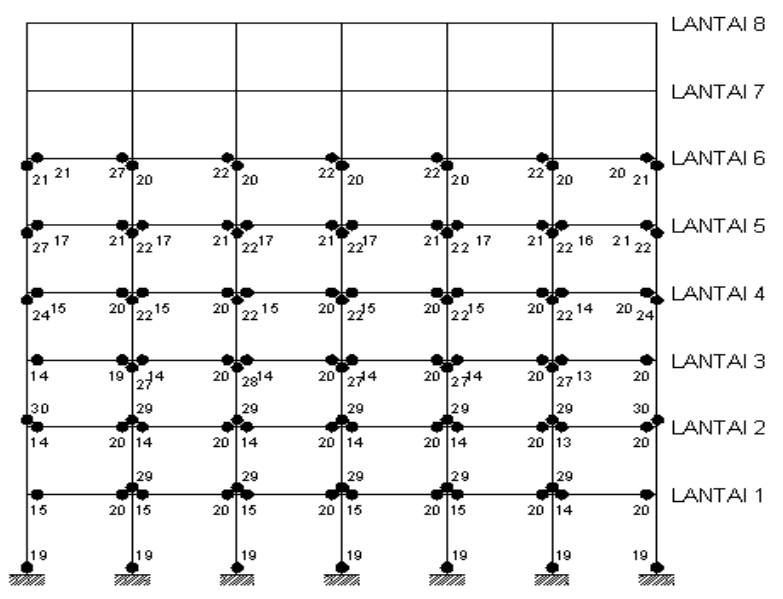

Gambar 10.b Lokasi Terbentuknya Sendi Plastis Sebelum Redistribusi Momen Portal XZ_3

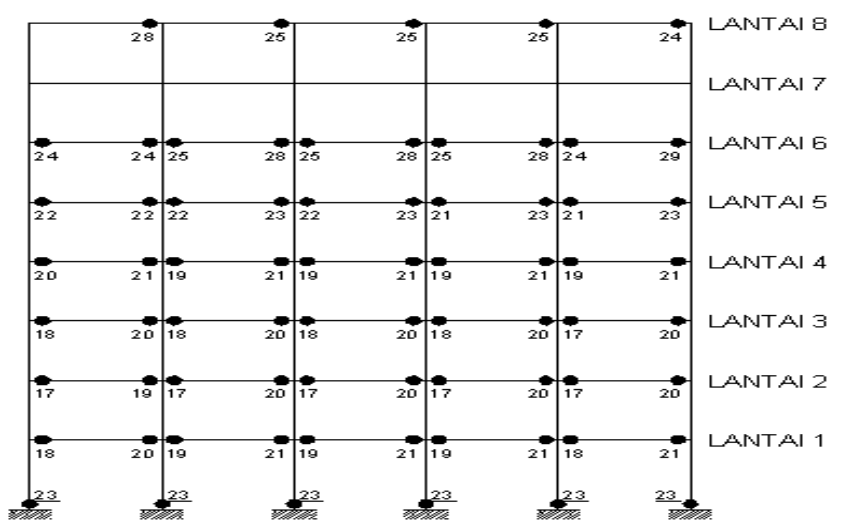

Gambar 11.c Lokasi Terbentuknya Sendi Plastis Sebelum Redistribusi Momen Portal YZ_1

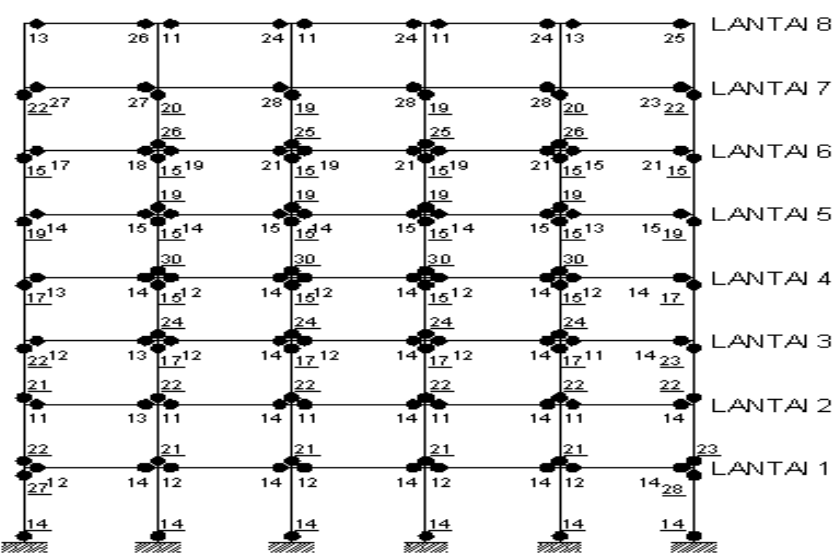

Gambar 11.d Lokasi Terbentuknya Sendi Plastis Sebelum Redistribusi Momen Portal YZ_4 


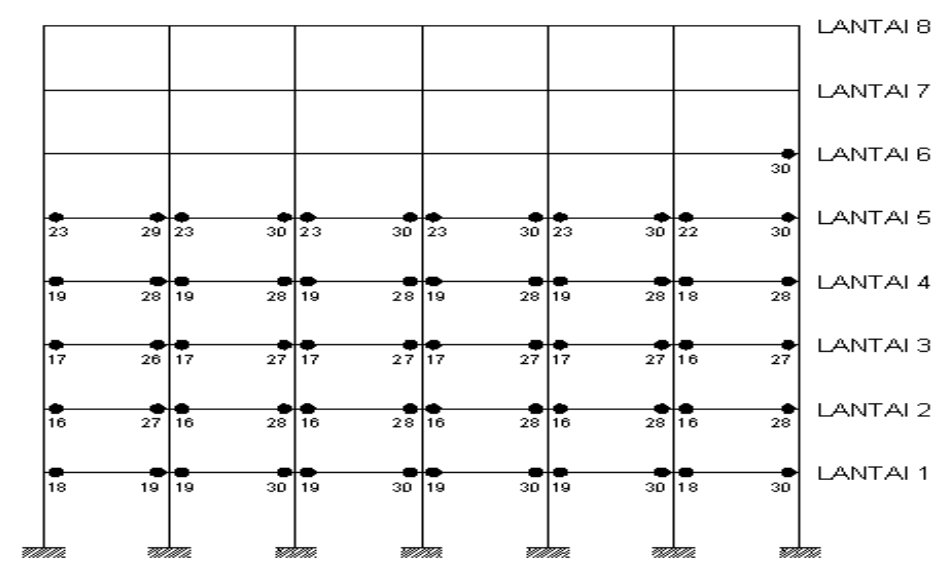

Gambar 11.a Lokasi Terbentuknya Sendi Plastis Sesudah Redistribusi Momen Portal XZ_1

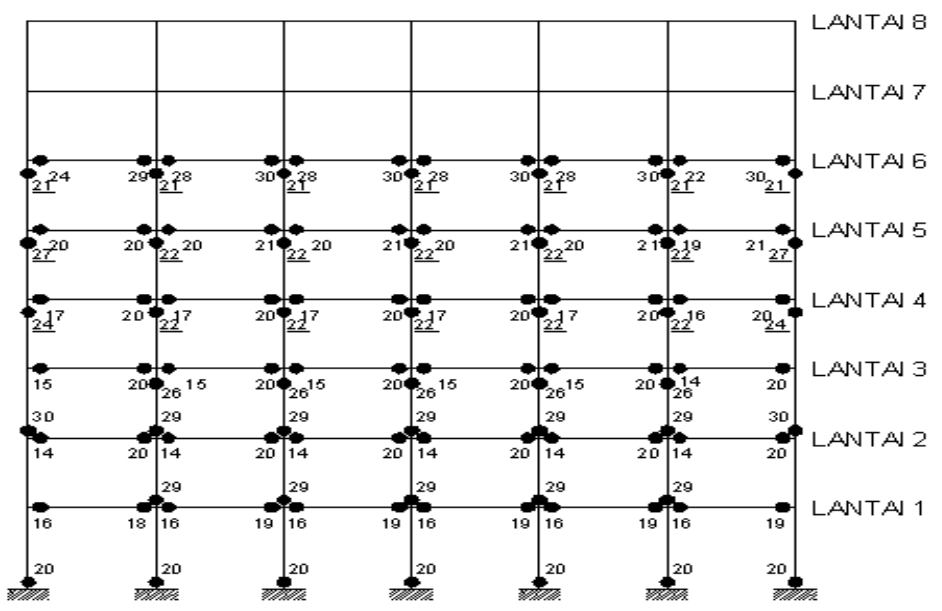

Gambar 11.b Lokasi Terbentuknya Sendi Plastis Sesudah Redistribusi Momen Portal XZ_3

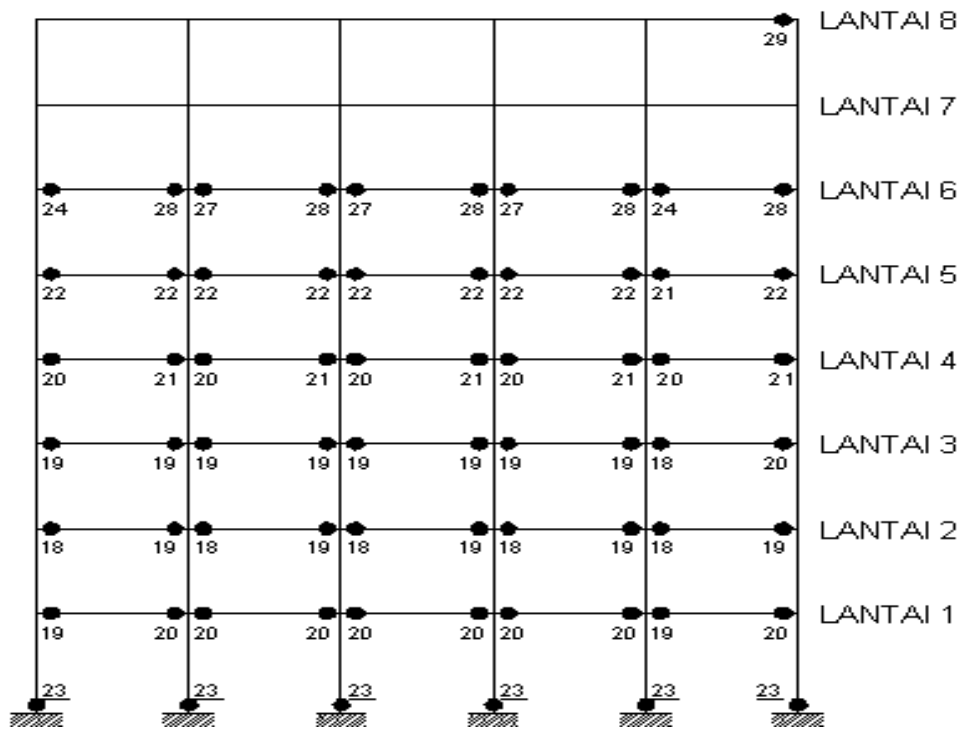

Gambar 11.c Lokasi Terbentuknya Sendi Plastis Sesudah Redistribusi Momen Portal YZ_1 


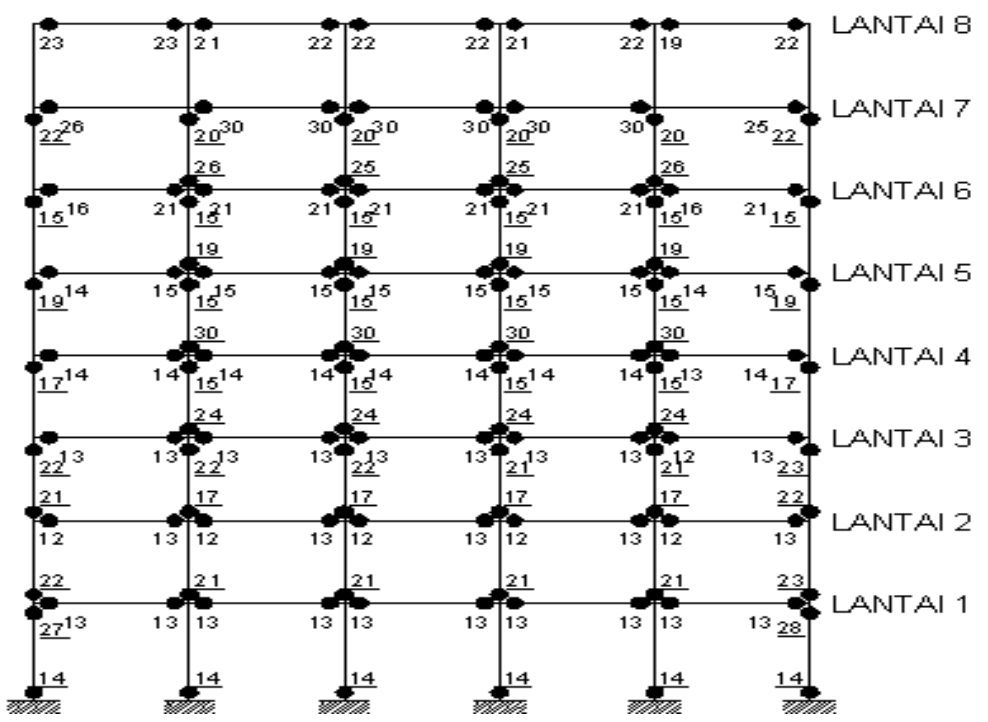

Gambar 11.d Lokasi Terbentuknya Sendi Plastis Sesudah Redistribusi Momen Portal YZ_4

Tabel 1 Besar Gaya Gempa yang menyebabkan terjadinya Sendi Plastis pada ujung-ujung balok

a. Portal XZ_1

\begin{tabular}{|c|c|c|c|c|}
\hline \multirow{2}{*}{$\begin{array}{l}\text { Balok Lantai } \\
\text { ke - }\end{array}$} & \multicolumn{2}{|c|}{ Sebelum Redistribusi V (KN) } & \multicolumn{2}{|c|}{ Setelah Redistribusi V (KN) } \\
\hline & Leleh Awal & Leleh Akhir & Leleh Awal & Leleh Akhir \\
\hline 1 & 8671.296 & 11875.352 & 7476.132 & 12307.646 \\
\hline 2 & 7806.709 & 11031.957 & 6531.020 & 11519.346 \\
\hline 3 & 7866.044 & 11002.289 & 6751.405 & 11315.914 \\
\hline 4 & 8696.725 & 11532.061 & 7628.706 & 11735.493 \\
\hline 5 & 9739.315 & 12303.408 & 8959.491 & 12413.600 \\
\hline 6 & 12218.644 & *** & 12307.646 & ${ }^{* \star}$ \\
\hline 7 & ** & ** & ** & ** \\
\hline 8 & $\star *$ & ** & ** & ** \\
\hline $\begin{array}{l}\text { Kaki Kolom } \\
\text { Terbawah }\end{array}$ & ** & ** & ** & ** \\
\hline
\end{tabular}

b. Portal XZ_3

\begin{tabular}{|c|c|c|c|c|}
\hline \multirow{2}{*}{$\begin{array}{l}\text { Balok Lantai } \\
\text { ke - }\end{array}$} & \multicolumn{2}{|c|}{ Sebelum Redistribusi V (KN) } & \multicolumn{2}{|c|}{ Setelah Redistribusi V (KN) } \\
\hline & Leleh Awal & Leleh Akhir & Leleh Awal & Leleh Akhir \\
\hline 1 & 5912.247 & 8332.242 & 6382.684 & 7857.567 \\
\hline 2 & 5306.189 & 8137.286 & 5619.813 & 8340.719 \\
\hline 3 & 5357.047 & 8150.001 & 5734.244 & 8370.386 \\
\hline 4 & 5899.533 & 8387.338 & 6755.643 & 8298.337 \\
\hline 5 & 6628.498 & 8569.580 & 7921.140 & 8514.484 \\
\hline 6 & 8429.720 & 11133.673 & 8967.968 & 12379.695 \\
\hline 7 & ** & $\approx *$ & $\approx *$ & 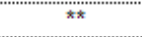 \\
\hline 8 & 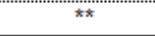 & 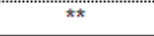 & 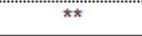 & 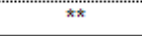 \\
\hline $\begin{array}{l}\text { Kaki Kolom } \\
\text { Terbawah }\end{array}$ & 7789.756 & ** & 8179.668 & ** \\
\hline
\end{tabular}


c. Portal $Y Z_{-} 1$

\begin{tabular}{|c|c|c|c|c|}
\hline \multirow{2}{*}{$\begin{array}{c}\text { Balok Lantai } \\
\text { ke - }\end{array}$} & \multicolumn{2}{|c|}{ Sebelum Redistribusi V (KN) } & \multicolumn{2}{|c|}{ Setelah Redistribusi V (KN) } \\
\hline & Leleh Awal & Leleh Akhir & Leleh Awal & Leleh Akhir \\
\hline 1 & 7446.465 & 8667.058 & 7921.140 & 8183.906 \\
\hline 2 & 6814.977 & 8222.050 & 7302.367 & 7870.282 \\
\hline 3 & 6929.408 & 8366.148 & 7471.894 & 8090.667 \\
\hline 4 & 7730.422 & 8828.108 & 8226.288 & 8573.818 \\
\hline 5 & 8599.247 & 9408.737 & 8870.490 & 9264.640 \\
\hline 6 & 9777.458 & 11955.878 & 9828.316 & 11680.397 \\
\hline 7 & $\star \star \star$ & $\star \star \star *$ & $\star \star *$ & $\star \star *$ \\
\hline 8 & 9908.841 & ** & 12104.214 & *** \\
\hline $\begin{array}{c}\text { Kaki Kolom } \\
\text { Terbawah }\end{array}$ & 9459.595 & 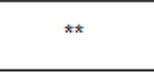 & 9480.786 & ** \\
\hline
\end{tabular}

d. Portal YZ_4

\begin{tabular}{|c|c|c|c|c|}
\hline \multirow{2}{*}{$\begin{array}{c}\text { Balok Lantai } \\
\text { ke - }\end{array}$} & \multicolumn{2}{|c|}{ Sebelum Redistribusi V (KN) } & \multicolumn{2}{c|}{ Setelah Redistribusi V $(\mathrm{KN})$} \\
\cline { 2 - 5 } & Leleh Awal & Leleh Akhir & Leleh Awal & Leleh Akhir \\
\hline 1 & 4721.321 & 5831.722 & 5183.282 & 5450.287 \\
\hline 2 & 4305.981 & 5543.526 & 4827.276 & 5200.235 \\
\hline 3 & 4378.030 & 5619.813 & 4950.183 & 5374.000 \\
\hline 4 & 4878.134 & 5861.389 & 5437.572 & 5700.339 \\
\hline 5 & 5479.954 & 5997.011 & 5857.151 & 5967.343 \\
\hline 6 & 6030.916 & 8853.537 & 6403.875 & 8713.678 \\
\hline 7 & 9701.171 & 11671.920 & 10527.614 & 12693.319 \\
\hline 8 & 4445.840 & 10955.669 & 7751.613 & 9650.313 \\
\hline $\begin{array}{c}\text { Kaki Kolom } \\
\text { Terbawah }\end{array}$ & 5645.242 & 11854.161 & 5755.435 & 11849.923 \\
\hline \multicolumn{5}{|c|}{ Belum leleh pada saat struktur runtuh } \\
\hline
\end{tabular}

Pada perencanaan sebelum redistribusi, sendi plastis pertama terjadi pada saat gaya gempa $4305.981 \mathrm{KN}$ dan keruntuhan terjadi pada 5645.242 KN . Pada perencanaan setelah redistribusi, sendi plastis pertama terjadi pada gaya gempa 4827.276 KN dan keruntuhan terjadi pada saat gaya gempa $5755.435 \mathrm{KN}$.

Hubungan antara gaya gempa dan simpangan level teratas struktur sebelum dan sesudah redistribusi momen diperlihatkan pada gambar 12 . Perhitungan daktilitas struktur ditabelkan pada tabel 2. 


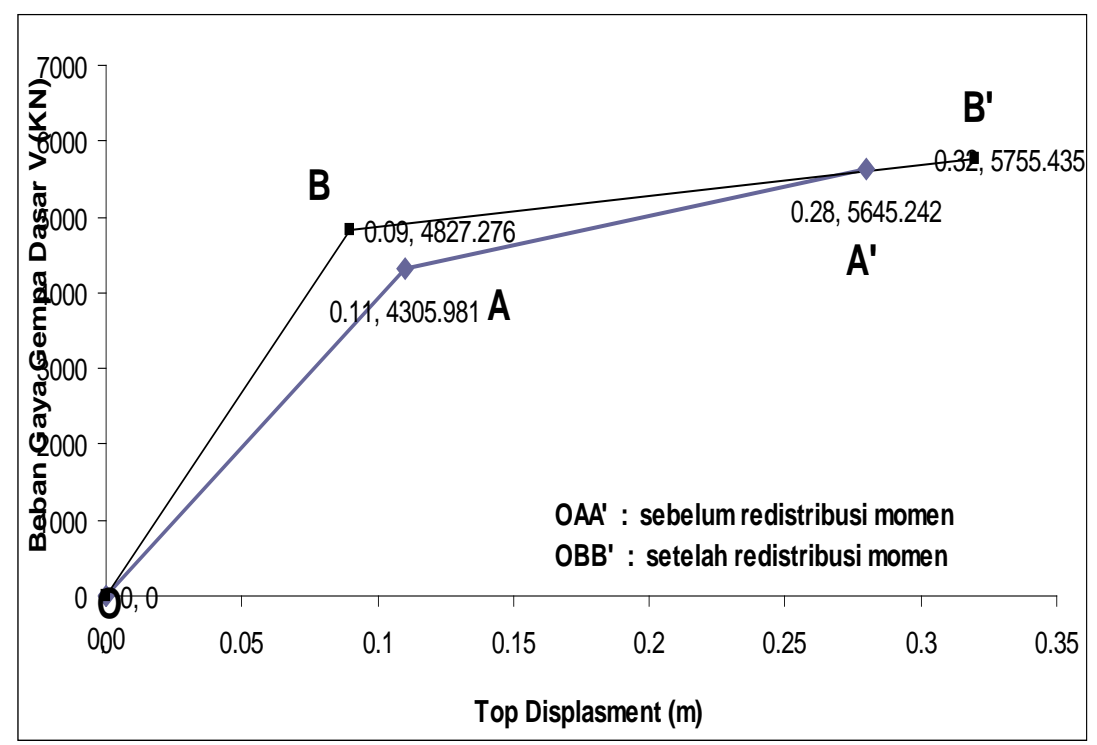

Gambar 12 Hubungan Perpindahan pada Puncak Struktur terhadap Gaya Gempa

Tabel 2 Daktilitas Struktur

\begin{tabular}{|c|c|c|}
\hline & Sebelum Redistribusi & Setelah Redistribusi \\
\hline $\begin{array}{l}\text { 1. Leleh Awal } \\
\text { 2. Saat Runtuh } \\
\text { 3. Daktilitas }(\mu=\delta \mathrm{c} / \delta \mathrm{y})\end{array}$ & $\begin{array}{c}V y=4305.981 \mathrm{KN} ; \delta y=0.11 \mathrm{~m} \\
V_{c}=5645.242 \mathrm{KN} ; \delta c=0.28 \mathrm{~m} \\
2.42\end{array}$ & $\begin{array}{c}V y=4827.276 \mathrm{KN} ; \delta y=0.09 \mathrm{~m} \\
V_{c}=5755.435 \mathrm{KN} ; \delta \mathrm{c}=0.32 \mathrm{~m} \\
3.58\end{array}$ \\
\hline
\end{tabular}

Dari tabel 2, daktilitas untuk perencanaan memenuhi apa yang disyaratkan untuk daktilitas parsial, $\mu=2.42$ untuk desain sebelum redistribusi dan $\mu=3.58$ untuk desain setelah redistribusi.

Kekakuan struktur pada kondisi elastis yang dinyatakan oleh tangen dari sudut yang dibentuk oleh garis OA dan OB pada gambar 4.8, apabila dinyatakan sebagai proporsi dari $V_{0}$ adalah sebesar 1.02 / 0.11 atau 1.14 / 0.09 atau sekitar 9.27 dan 12.67. Simpangan yang terjadi pada puncak struktur untuk Taraf Gempa Sangat Kuat dimana $V=4 V_{0}$ adalah sebesar $4 / 9.27=0.43 \mathrm{~m}$. Pada kondisi ini, untuk struktur yang telah didesain, baik sebelum maupun setelah redistribusi, struktur masih dapat 
melakukan simpangan antar tingkat inelastik. Plastifikasi yang terjadi pada balok sudah demikian luas dan dapat diperkiraan sudah mengalami kerusakan yang berat, tetapi mash dapat diperbaiki karena struktur secara keseluruhan masih berdiri.

Dataran leleh (yield plateau) yang cukup panjang menunjukkan bahwa struktur masih berperilaku elasto-plastik dan melakukan simpangan yang inelastik, bahkan pada saat gaya gempa melebihi taraf Gempa Sangat Kuat. Secara keseluruhan diamati bahwa struktur tersebut memiliki kinerja yang cukup baik ditinjau dari aspek perilaku struktur pada saat gaya gempa rencana bekerja pada struktur tersebut.

Telah dijelaskan sebelumnya, bahwa redistribusi momen dilakukan dengan mempertahankan gaya geser dasar rencana. Dengan demikian seharusnyalah kedua desain yaitu sebelum dan sesudah redistribusi, mempunyai kurva gaya-perpidahan yang berimpit pada bagian akhirnya. Tetapi gambar 4.8 tidak menunjukkan hal ini. Adanya syarat bahwa luas tulangan bawah balok pada bagian perletakan minimal 1/2 dari tulangan bagian atasnya yang menyebabkan hal ini. Untuk desain dengan redistribusi momen, syarat ini umumnya terpenuhi secara otomatis karena momen negatif yang direduksi dan momen positif yang ditingkatkan. Sementara pada desain sebelum redistribusi, lebih banyak dibutuhkan tulangan positif tambahan agar syarat tersebut dipenuhi.

\section{KESIMPULAN}

Berdasarkan analisis data yang dilakukan dalam penelitian ini, maka dapat ditarik beberapa kesimpulan sebagai berikut :

1. Akibat beban layan pada struktur tidak secara langsung mempengaruhi daktilitas suatu struktur. Ini disebabkan dalam desain redistribusi momen menggunakan momen plastis dimana balok didesain secara keselurahan.

2. Simpangan maksimum struktur setelah penerapan redistribusi momen sebesar $0.32 \mathrm{~m}$, dan sebelum penerapan redistribusi momen sebesar 
$0.28 \mathrm{~m}$. Ini berarti redistribusi momen tidak mengurangi besarnya simpangan maksimum yang dapat dicapai struktur.

3. Leleh awal struktur sebelum penerapan redistribusi momen lebih dahulu terjadi saat beban gempa nominal akibat gempa rencana pada tingkat dasar yaitu $4305.981 \mathrm{KN}$ dibandingkan dengan setelah penerapan redistribusi momen yaitu $5645.242 \mathrm{KN}$ dan saat runtuh sebelum redisribusi momen lebih dahulu yaitu $4827.276 \mathrm{KN}$ dibandingkan dengan setelah penerapan redistribusi momen yaitu $5755.435 \mathrm{KN}$.

4. Daktilitas struktur setelah penerapan redistribusi momen sebesar 3.58 dan sebelum penerapan redistribusi momen sebesar 2.42. Ini berarti redistribusi momen berpengaruh terhadap peningkatan faktor daktilitas walaupun hasil analisis dengan redistribusi momen didapat pengurangan momen rata-rata sebesar $30 \%$.

\section{DAFTAR PUSTAKA}

1. $\mathrm{ACl}$ Committe 318, 2005. Building Code requirements for Structural Concrete and Commentary (ACl 318M-05). ACl, Detroit.

2. Departemen PU, 2002. Standar Perencanaan Ketahanan Gempa Untuk Struktur Bangunan Gedung (SK-SNI 03-1726-2002). Badan Standarisasi Nasional,Jakarta.

3. Departemen PU, 2002. Tata Cara Perhitungan Struktur Beton Untuk Bangunan Gedung (SK-SNI 03-2847-2002). Badan Standarisasi Nasional,Jakarta.

4. Habibullah, Ashraf, 2005. SAP User Manual Version 10.0.1 Advanced, Computer \& Structures, Inc, Berkeley California.

5. Mac Gregor, J.G., 1997. Reinforced Concrete : Mechanics and Design. Prentice Hall. 
6. Paulay, T., and Priestley, M.J.N., 1992. Seismic Design of Reinforced Concrete and Masonry Buildings. John Wiley \& Sons.

7. Park, R. and Paulay, T.,1975. Reinforced Concrete Structures. John Wiley \& Sons.

8. Portland Cement Association, 1992. PCACOL Strength Design Of Reinforced Column Section, Concrete Design Software Library. Skokie, IL.

9. Prakash, V., Powell, G.H.,1993. Drain-2Dx Base Program and User Guide Version 1.10, Departement of Civil Engineering, University of California, Berkeley.

10. Purwono, Rachmat, dkk, 2006. Perencanaan Struktur Beton Bertulang Tahan Gempa (Sesuai SNI-1726 dan SNI-2847 terbaru), ITS Press, Surabaya.

11. Purwono, Rachmat, dkk, 2007. Tata Cara Perhitungan Struktur Beton Untuk Bangunan Gedung (SNI 03-2847-2002) dilengkapi Penjelasan (S-2002), ITS Press, Surabaya.

12. Tanijaya, Jonie, 2003. Diktat Perilaku Daktail Struktur Beton, Program Pascasarjana, Universitas hasanuddin, Makassar. 